\title{
Analysis of Magnetic Resonance Imaging Findings in Patients with Migraine
}

\author{
Amarjit Kaur ${ }^{\oplus 1}$, Simmi Bhatnagar ${ }^{2}$, Navkiran Kaur ${ }^{\oplus 3}$, Dimple Mittal ${ }^{\oplus 4}$, Ishita Gupta $\oplus^{4}$ \\ ${ }^{1}$ Professor, Department of Radiodiagnosis, GMC, Patiala, Punjab, India, ${ }^{2}$ Associate Professor, Department of Radiodiagnosis, GMC, Patiala, Punjab, India, ${ }^{3}$ Professor and \\ Head, Department of Radiodiagnosis, Govt. Medical College, Rajindra Hospital, Patiala, Punjab, India, ${ }^{4}$ Junior Resident, Department of Radiodiagnosis, GMC, Patiala, \\ Punjab, India.
}

\section{Abstract}

Background: Migraine is a common disabling brain disorder. Headache accounts for $4.4 \%$ of all consultations in general practice, approximately $5 \%$ of all medical admissions to hospital, and approximately $20 \%$ of neurology outpatient consultations. Hence, the present study was undertaken for assessing the MRI findings in patients with migraine. Subjects and Methods: A total of 5 patients with migraine headache were included in the present study. Complete demographic details of all the patients were obtained. Thorough clinical examination was carried out and routine hematological and other biochemical investigations were also done. Patients underwent MRI investigations. Imaging was performed using a head coil with patient in a supine position. All the MR imaging examination were performed on a Seimen's Avento 1.5 Tesla Magnet MR System, slice thickness was $4-5 \mathrm{~mm}$ with an inter slice gap of $0.5 \mathrm{~mm}$. MR imaging findings were compiled as per proforma and subjected to analysis using SPSS software. Results: Out of 5 migraine patients, significant abnormal MRI findings were present in 40 percent of the patients. One patient showed T2and T2 FLAIR Hyperintensities in subcortical white matter in frontal region. In the second patient with migraine, MRI finding revealed an area of diffusion restriction in left basal ganglia region which was hypointense on T1, T2 FLAIR and Hyperintense on T2 consistent with chronic infarct. Conclusion: Migraine headache patient occasionally have abnormal MRI findings to explain their headaches. Neuroimaging of headache sufferers in the general population yields few findings of clinical importance.

Keywords: Magnetic resonance imaging, Migraine

Corresponding Author: Simmi Bhatnagar, Associate Professor, Department of Radiodiagnosis, GMC, Patiala, Punjab, India. E-mail: hkps0320@gmail.com

Received: 19 December 2020

Revised: 21 January 2020

\section{Introduction}

Migraine is a common disabling brain disorder. Headache accounts for $4.4 \%$ of all consultations in general practice, approximately $5 \%$ of all medical admissions to hospital, and approximately $20 \%$ of neurology outpatient consultations. ${ }^{[1-3]}$ Migraine affects over $20 \%$ of people at some point in their lives; epidemiological studies have shown that $4.5 \%$ of the population of Western Europe has headache on at least 15 days per month; global studies suggest that approximately $1 \%$ of the world's population may have chronic migraine. Chronic migraine imposes a substantial economic burden on society. Migraine is so common that, even though for many people it is no more than an inconvenience. ${ }^{[4]}$

According to US Guidelines on Neuroimaging in Patients with Non-Acute Headache, Non-acute (or chronic) headache is defined as all headache syndromes lasting for at least four weeks. ${ }^{[1]}$ For physicians not experienced in headache disorders it might be difficult sometimes to decide, whether neuroimaging is necessary or not to diagnose an underlying brain pathology. Many patients are frightened that they are suffering from a severe disease and therefore request further diagnostics. ${ }^{[5-7]}$ From an Indian perspective; few studies describe the epidemiology of headache disorders. Previously, these disorders have been investigated only within larger neuroepidemiological surveys that have neither focused on headache nor used internationally accepted criteria for headache diagnosis. ${ }^{[8]}$ hence; the present study was undertaken for assessing the MRI findings in patients with migraine.

\section{Subjects and Methods}

The present study was conducted in the department of Radio-diagnosis of Rajindra Hospital, Patiala, and it included assessment of role of MRI scan in persons with Migraine. A 
total of 5 patients with migraine were included in the present study. Ethical approval was obtained from institutional ethical committee and written consent was obtained from all the patients after explaining in detail the entire research protocol. Complete demographic details of all the patients were obtained. Thorough clinical examination was carried out and routine haematological and other biochemical investigations were also done. Patients underwent MRI investigations. Imaging was performed using a head coil with patient in a supine position. All the MR imaging examination were performed on a Seimen's Avento 1.5 Tesla Magnet MR System, slice thickness was $4-5 \mathrm{~mm}$ with an inter slice gap of $0.5 \mathrm{~mm}$. MR imaging findings were compiled as per proforma and subjected to analysis using SPSS software. Chi- square test was used for assessment of level of significance.

\section{Results}

In the present study, a total of 5 patients with migraine were analysed. Mean age of the patients was found to be 42.8 years. Out of these 5 patients, 3 patients were males while the remaining 2 were females. Out of 5 migraine patients, significant abnormal MRI findings were present in 40 percent of the patients. One patient showed T2and T2 FLAIR Hyperintensities in subcortical white matter in frontal region. In the second patient with migraine, MRI finding revealed an area of diffusion restriction in left basal ganglia region which was hypointense on T1, T2 FLAIR and Hyperintense on T2 consistent with chronic infarct.

\section{Discussion}

Primary headache (i.e., migraine and tension headache) is the majority of headache patients presenting to a primary care practice, $76 \%$ of which are migraine. Migraine is the third most prevalent disorder worldwide and second most disabling, affecting more women than men. According to the International Classification of Headache Disorders, 3rd Edition (ICHD-III) criteria, migraine attacks should last between 4 and $72 \mathrm{~h}$, and have at least two of the four following criteria: (1) unilateral location, (2) pulsating pain, (3) moderate to severe intensity, and (4) aggravated by routine physical activity. There must also have at least one of the following: (1) nausea and/or vomiting and (2) photophobia and phonophobia. ${ }^{[8,9]}$ Hence; the present study was undertaken for assessing the MRI findings in patients with migraine.

In the present study, a total of 10 patients with migraine were analysed. Mean age of the patients was found to be 42.8 years. Out of these 10 patients, 7 patients were males while the remaining 3 were females. MRI plays a role in the emergent evaluation of seizures, although the evidencebased review was unable to make recommendations because of limited data. In patients with red flags, an inconclusive CT scan should prompt consideration of an emergent brain MRI. MRI provides greater soft tissue contrast and may identify pathologies missed on $\mathrm{CT}$, such as small or hyperacute stroke, embolic shower, cerebral venous sinus thrombosis, low-grade tumors, small metastases, posterior reversible encephalopathy syndrome (PRES), herpes simplex virus encephalitis, or leptomeningeal disease. A patient presented after few episodes of severe headache may harbour considerable anxiety and fear of brain tumour or many other serious diseases which not only badly affect person's behaviour, psychology and even economic benefit in terms of productivity from their job. The assessment of value for loss is inherently very subjective and difficult to measure. So one practically possible way to do so would be simply ask the patient or relatives how much they would be willing to pay for neuroimaging which would diagnose or exclude significant pathology of brain. ${ }^{[8,9]}$

In the present study, out of 5 migraine patients, significant abnormal MRI findings were present in 40 percent of the patients. One patient showed T2and T2 FLAIR Hyperintensities in subcortical white matter in frontal region. In the second patient with migraine, MRI finding revealed an area of diffusion restriction in left basal ganglia region which was hypointense on T1, T2 FLAIR and Hyperintense on T2 consistent with chronic infarct. Ferbert A et al investigated MRI pattern of a total of 45 patients suffering from classic migraine; 25 patients had been treated in our department for classic migraine over the past 2 years (group A), and 20 other patients investigated between 1976 and 1984 were reexamined for this study (group B). Thirty-two age- and roughly sex-matched healthy volunteers underwent magnetic resonance imaging and served as controls (group C). There was a trend for patients with classic migraine to have more subcortical patchy lesions on T2 weighted magnetic resonance imaging. In a comparison of our control subjects and patients with a history of $>20$ attacks of classic migraine taken from groups $\mathrm{A}$ and $\mathrm{B}$, this difference in number of lesions was significant $(/ 7=\mathrm{O} . \mathrm{O} 2)$. The results suggest that patchy lesions in patients with classic migraine should be interpreted with particular caution before diagnosing a demyelinating disease since the lesions could be ischemic in origin. ${ }^{[10]}$ Lewis DW et al assessed the utility of neuroimaging in the evaluation of children presenting with two of the most common forms of headache, migraine and chronic daily headache, and to determine the utility and pathological yield of neuroimaging in specific headache syndromes in children whose neurological examinations are normal. Twelve (11.2\%) patients with migraine received an MRI, 2 (16.7\%) of which were considered abnormal. Both of the abnormal findings were Chiari type I malformations. Eight (26.7\%) of the patients with chronic daily headache had an MRI, 2 (25.0\%) of which were abnormal. One of the abnormalities was a Chiari I malformation, and the other was an occult vascular malformation. The yield of neuroimaging in children with uncomplicated 


\begin{tabular}{|c|c|c|c|c|c|c|c|c|c|}
\hline \multirow[t]{2}{*}{ Parameter } & \multicolumn{3}{|c|}{$\begin{array}{l}\text { Presence of significant MRI find- } \\
\text { ings }\end{array}$} & \multirow{2}{*}{$\begin{array}{l}\begin{array}{l}\text { Absence } \\
\text { findings }\end{array} \\
\text { Number } \\
\text { patients }\end{array}$} & \multicolumn{2}{|c|}{ of significant MRI } & \multicolumn{3}{|l|}{ Total } \\
\hline & $\begin{array}{l}\text { Number } \\
\text { patients }\end{array}$ & of & $\begin{array}{l}\text { Percentage of } \\
\text { patients }\end{array}$ & & of & $\begin{array}{l}\text { Percentage of } \\
\text { patients }\end{array}$ & $\begin{array}{l}\text { Number } \\
\text { patients }\end{array}$ & of & $\begin{array}{l}\text { Percentage } \\
\text { patients }\end{array}$ \\
\hline Migraine & 2 & & 40 & 3 & & 60 & 5 & & 100 \\
\hline
\end{tabular}

\begin{tabular}{|c|c|c|c|c|c|}
\hline $\begin{array}{l}\text { Number of } \\
\text { patients }\end{array}$ & T1 & T2 & T2 Flair & DWI & SWI \\
\hline 1 & - & $\begin{array}{l}\text { Hyperintensiti } \\
\text { in bilat- } \\
\text { eral peri- } \\
\text { ventricular } \\
\text { white matter } \\
\text { and centrum } \\
\text { semi-ovale }\end{array}$ & $\begin{array}{l}\text { Hyperintensities } \\
\text { in bilateral peri- } \\
\text { ventricular white } \\
\text { matter and cen- } \\
\text { trum semi-ovale }\end{array}$ & - & - \\
\hline 1 & $\begin{array}{l}\text { Hypointense area in } \\
\text { Left basal ganglia } \\
\text { region }\end{array}$ & $\begin{array}{l}\text { Hyperintense } \\
\text { area at Left } \\
\text { basal gan- } \\
\text { glia region }\end{array}$ & $\begin{array}{l}\text { Hypointense area } \\
\text { in left basal gan- } \\
\text { glia region }\end{array}$ & $\begin{array}{l}\text { Restricted diffu- } \\
\text { sion inleft basal } \\
\text { ganglia region }\end{array}$ & - \\
\hline
\end{tabular}

migraine and normal neurological examination was 3.7\%. The yield in children with chronic daily headache and normal neurological examination was higher at $16.6 \%{ }^{[11]}$

\section{Conclusion}

Migraine patient occasionally have abnormal MRI findings to explain their headaches. Neuroimaging of headache sufferers in the general population yields few findings of clinical importance. However; further studies are recommended.

\section{References}

1. Rai GS, Rai T, Jain L, Vyas MM, Roshan R. Evaluation of $\mathrm{CT}$ and MRI Findings among Patients Presented with Chief Complaint of Headache in Central India. J Clin Diagn Res. 2016;10(2):21-21. Available from: https://dx.doi.org/10.7860/ JCDR/2016/16852.7249.

2. Lucato LT, Guedes MS, Sato JR, Bacheschi LA, Machado LR, Leite CC. The Role of Conventional MR Imaging Sequences in the Evaluation of Neurocysticercosis: Impact on Characterization of the Scolex and Lesion Burden. Am J Neuroradiol. 2007;28(8):1501-1504. Available from: https: //dx.doi.org/10.3174/ajnr.a0623.

3. Arora V, Nijjar IBS, Mahajan DS, Sandhu PS, Singh JP, Chopra R. MRI in seizure disorder - a pictorial essay. Indian J Radiol Imaging. 2005;15(3):331-331. Available from: https: //dx.doi.org/10.4103/0971-3026.29148.

4. Altman DA, Atkinson DS, Brat DJ. Best Cases from the AFIP Glioblastoma Multiforme. Radiographics. 2007;27:883-888.
Available from: https://dx.doi.org/10.1148/rg.273065138.

5. Holle D, Obermann M. The role of neuroimaging in the diagnosis of headache disorders. Ther Adv Neurol Disord. 2013;6(6):369-374. Available from: https://dx.doi.org/10. 1177/1756285613489765.

6. Ferbert A, Busse D, Thron A. Microinfarction in classic migraine? A study with magnetic resonance imaging findings. Stroke. 1991;22(8):1010-1014. Available from: https://dx.doi. org/10.1161/01.str.22.8.1010.

7. Lewis DW, Dorbad D. The Utility of Neuroimaging in the Evaluation of Children With Migraine or Chronic Daily Headache Who Have Normal Neurological Examinations. Headache J Head Face Pain. 2000;40(8):629-632. Available from: https: //dx.doi.org/10.1046/j.1526-4610.2000.040008629.x.

8. Swartz RH, Kern RZ. Migraine Is Associated With Magnetic Resonance Imaging White Matter Abnormalities. Arch Neurol. 2004;61(9):1366-1366. Available from: https://dx.doi.org/10. 1001/archneur.61.9.1366.

9. Agarwal S, Magu S, Kamal K. Reversible white matter abnormalities in a patient with migraine. Neurol India. 2008;56:182-182. Available from: https://dx.doi.org/10.4103/ 0028-3886.41998. doi:10.4103/0028-3886.41998.

10. Ferbert A, Busse D, Thron A. Microinfarction in classic migraine? A study with magnetic resonance imaging findings. Stroke. 1991;22(8):1010-1014. Available from: https://dx.doi. org/10.1161/01.str.22.8.1010.

11. Lewis DW, Dorbad D. The Utility of Neuroimaging in the Evaluation of Children With Migraine or Chronic Daily Headache Who Have Normal Neurological Examinations. Headache J Head Face Pain. 2000;40(8):629-632. Available from: https: //dx.doi.org/10.1046/j.1526-4610.2000.040008629.x. 
Copyright: (C) the author(s), 2020. It is an open-access article distributed under the terms of the Creative Commons Attribution License (CC BY 4.0), which permits authors to retain ownership of the copyright for their content, and allow anyone to download, reuse, reprint, modify, distribute and/or copy the content as long as the original authors and source are cited.

How to cite this article: Kaur A, Bhatnagar S, Kaur N, Mittal D, Gupta I. Analysis of Magnetic Resonance Imaging Findings in Patients with Migraine. Asian J. Med. Radiol. Res. 2020;8(1): 28-31.

DOI: dx.doi.org/10.47009/ajmrr.2020.8.1.5

Source of Support: Nil, Conflict of Interest: None declared. 